УДК 130.123:316.3

В. С. Ігнатко, к. ю. н.

\title{
ДУХОВНЕ ОНОВЛЕННЯ УКРАЇНСЬКОГО СУСПІЛЬСТВА В КОНТЕКСТІ ЄВРОПЕЙСЬКИХ ТРАДИЦІЙ
}

Актуальність теми дослідження. Європейський вибір України передбачає очищення від нашарувань тоталітарного суспільства, утвердження нової духовності і моралі, які б відповідали національним традиціям і загальнолюдськими нормам життєдіяльності.

Постановка проблеми. Цей процес визначає необхідність теоретико-методологічного осмислення процесу духовного оновлення національного простору.

Аналіз останніх досліджень і публікацій. Питання зміни ціннісних орієнтирів українців розелядають Є. Борінштейн, Е. Кац, В. Колесніченко, А. Кудряченко, М. Пірен, В. Рибалка, І. Русенко та інші. Проблеми духовної складової трансформаційних процесів в Україні розглядають Є. Борінштейн, Е. Кац, В. Колесніченко, А. Кудряченко, М. Пірен, В. Рибалка, І. Русенко тощо.

Виділення недосліджених частин загальної проблеми. Поза увагою дослідників знаходиться хід рушійних змін духовної складової вітчизняної спільноти.

Постановка завдання. Розглянути процес оновлення українського суспільства в основі, котрого лежать європейські цінності.

Виклад основного матеріалу. Загальнолюдські цінності передбачають насамперед єдність людського роду на засадах людиноцентризму, гідності, миру $і$ справедливості. Здійснюється аналіз особливих ціннісних категорій, що вироблені століттями в історії людства і визнані ним як загальні, належать наступні етичні погляди, моральні принципи й установки людини: добро, благородство, справедливість, честь, гідність $і$ як вищий прояв духовності - гуманізм у ставленні до людей і стосунках між ними.

Висновки. Формування демократичних цінностей, визначених історією європейського континенту, є для України свідченням духовно-морального відродження.

Ключові слова: людина; культура; мораль; право; відродження; цінності.

V. S. Ihnatko, Candidate of Juridical Sciences

\section{SPIRITUAL RENOVATION OF UKRAINIAN SOCIETY IN THE CONTEXT OF EUROPEAN TRADITIONS}

Urgency of the research. The choice of Europe by Ukraine involves clearing from the layers of a totalitarian society, establishing a new spirituality and morality that would correspond to national traditions and universal human life standards.

Target setting. This process determines the need for theoretical and methodological understanding of the process of national space spiritual renewal.

Actual scientific researches and issues analysis. The issues of changing the value orientations of Ukrainians and of the spiritual component of transformational processes in Ukraine are studied by Ye. Borinshtein, E. Kats, V. Kolesnichenko, A. Kudriachenko, M. Piren, V. Rybalka, I. Rusenko et al.

Uninvestigated parts of general matters defining. The course of the moving changes in the spiritual component of the domestic community is beyond the attention of researchers.

The research objective. To consider the process of updating Ukrainian society with the heart at European values.

The statement of basic materials. Human values presuppose, first of all, the unity of the human race on the basis of humanocentrism, dignity, peace and justice. Special value categories were studied. These categories developed for centuries in the history of mankind and recognized as general, includes the following ethical views, moral principles and man's attitudes: goodness, nobility, justice, honor, dignity, and as the highest manifestation of spirituality - humanism in relation to people and relations between them. 
Conclusions. The formation of democratic values, determined by the history of the European continent, is evidence of spiritual and moral revival for Ukraine.

Keywords: man; culture; moral; law; revival; values.

DOI: 10.25140/2412-1185-2018-2(12)-44-50

Актуальність теми дослідження. Разом з поняттям загальнолюдські цінності набула поширення категорія європейські цінності. До них як аксіологічних принципів була прикута увага у переломні періоди поступу країн Європи ще від часів Великої Французької революції і потрясінь середини XIX ст., так і у XX та на початку XXI ст. Ці цінності постають частиною загального європейського цивілізаційного надбання, до якого входять настанови раннього християнства, античності, епохи Відродження і європейських буржуазно-демократичних революцій, а нині й досвід самої європейської інтеграції.

Постановка проблеми. Нині на зламі століть вони багато в чому подібні до цінностей американської мрії, їм не чужі соціальні гасла соціалізму та періоду подолання «холодної війни» в Європі. Водночас, певно, що ці цінності є духовним мірилом, що вбирає уявлення про добро і зло, справедливість і несправедливість, допустиме і недопустиме у практиці взаємовідносин $[1$, c. 62].

Аналіз останніх досліджень і публікацій. Проблеми духовної складової трансформаційних процесів в Україні розглядають $€$. Борінштейн, Е. Кац, В. Колесніченко, А. Кудряченко, М. Пірен, В. Рибалка, І. Русенко та інші. Дослідники сходяться на думці, що до особливих ціннісних категорій, що вироблені століттями в історії людства і визнані їм як загальні належать наступні етичні погляди, моральні принципи й установки людини: добро, благородство, справедливість, честь, гідність і як вищий прояв духовності - гуманізм у ставленні до людей і стосунках між ними.

Виділення недосліджених частин загальної проблеми. Водночас процес утвердження загальнолюдських цінностей в умовах сучасних українських реалій $є$ недостатньо дослідженим.

Постановка завдання. Розглянути духовно оновлене українське суспільство в контексті Європейських традицій.

Виклад основного матеріалу. Більш того, сама Європа нині постає не стільки географрічним поняттям, скільки ціннісним, бо європейські цінності складають основні підвалини ліберально-демократичних інститутів західноєвропейського простору, кордони якого не обмежуються географрічними ознаками приналежності країн до європейської частини світу. Європейські цінності втілені та втілюються і в Америці, і в Азії, і в Австралії. Адже саме Європа дала людству світську філософрію, християнство в якості світової релігії, релігійну терпимість, толерантність до переконань інших людей та інших цінностей.

Стрижнем європейських цінностей виступають ліберальні фундаментальні права та свободи людини, демократичні принципи державного устрою, а також правова і соціальна держава.

Будучи поєднанням ліберальних та демократичних ідей, європейські цінності позначаються як «ліберально-демократичні». Саме останні постали в якості принципів фуннціонування державних і політичних інститутів сучасних європейських країн та Європейського Союзу [2]. Тому сьогодні європейські цінності міцно пов'язані з основоположні принципами європейської інтеграції, що чітко визначені в Хартії фундаментальних прав Європейського Союзу від 7 грудня 2000 р. (м. Ніцца, Франція). У Преамбулі цього документі зазначається: «Народи Європи, утворюючи все більш згуртований і тісний союз, прийняли рішення будувати разом мирне майбутнє на основі загальних цінностей». Й далі, «усвідомлюючи своє духовне і моральне надбання, Європейський Союз ґрунтується на неподільних і загальних цінностях - гідності людини, свободи, рівності й солідарності» [3]. Перераховані цінності є частинами загального духовного та культурного спадку Європи, який базується на поєднанні грецької фрілософрії, романського права, християнства, гуманізму, просвітництва, духовності [4, с. 83].

Кожній з чотирьох окреслених вище цінностей присвячено окремий розділ Хартії. Розділи у свою чергу поділені на статті, у яких висвітлюється особливості реалізації окремих прав та норм. Деякі із статей повторюють положення прийнятих раніше міжнародних документів - Конвенції 
про захист прав людини і основоположних свобод, що прийнята Радою Європи 4 листопада 1950 р., Європейської соціальної хартії Ради Європи, прийнятої 3 травня 1996 р. тощо.

Звертаючись до тексту документу, М. Пірен пропонує розширений перелік європейських цінностей. У ньому, окрім окреслених безпосередньо в Преамбулі Хартії, значаться наступні цінності: фрундаментальні права, включаючи права спільнот та родин; волевиявлення, свобода слова, свобода 3Ml; демократія; рівність усіх членів суспільства, включаючи меншини та незалежно від гендеру; верховенство закону; плюралізм думок; відсутність дискримінації; толерантність; справедливість; відповідальність; рівні гендерні права; єдність; згуртованість [там же, с. 82-83]. Як можна побачити, цей перелік складають не суто моральні, а скоріше суспільнополітичні цінності, в центрі яких перебуває людина. Адже головною ідеєю Хартії $€$ те, що людську особистість Європейський Союз вважає центральною у своїй діяльності, надає їй «громадянство Союзу та створює простір свободи, безпеки та правосуддя» [3].

Отже, визначені в Хартії цінності Європейського Союзу є нічим іншим як загальними принципами права ЄС найбільш високого порядку («мегапринципи»), що відображають основні засади, які утворюють правове надбання сучасної європейської цивілізації, дотримання яких гарантовано на високому - наднаціональному рівні. Якщо цим «мегапринципам» надати правового життя, то їх можна назвати і принципами-цінностями. Багато які з них (свобода, демократія, правова держава, повага прав людини та основних свобод) раніше було закріплено у ст. 6 Договору про Європейський Союз 1992 р., де їх було названо «принципами» [5, с. 11]. Разом з тим, очевидно свідомо використовується слово «цінність» - поняття, що належить до сфери моралі (моральності), а не права як юридичного явища.

Філософське усвідомлення необхідності побудови $€ С$ на загальнолюдських цінностях логічно випливає із самого призначення такого союзу. Для прикладу, преамбула проекту Конституції 2005 р. описувала Європу як привілейований простір людської надії, «усвідомлюючи, що Європа $€$ континентом, який несе цивілізацію; що його жителі, які приходили послідовними хвилями 3 перших років існування людства, послідовно розвивали там цінності, що затверджують гуманізм: рівність людей, свободу, повагу до розуму» [6, р. 9].

Принципи права, що закладають основні засади правового розвитку, акумулюють у собі найважливіші цінності, які $є$ історичним здобутком цивілізації та зосереджені на потребах людини. Більше того, такі цінності виявляють людське благо, що сприяє подальшому суспільному розвитку [7, с. 236].

Отже, європейці створили систему - Європейський Союз, щоб підтримувати та захищати свої цінності. Європейський канон цінностей не обмежений національними кордонами - зауважив у свій час президент Німеччини Йоахім Гаук, - і вони дієві більше нашими національними, етнічними, культурними та релігійними особливостями. А британський дослідник сучасної історії профр. Тімоті Гартон Аш вважає, що необхідно постійно нагадувати про цінності та наголошувати на здобутках Європи для кожного покоління. Такі цінності, як свобода, справедливість чи мир це мета, а Європа - це лише засіб їх втілення, взірець для країн та народів світу, як облаштувати по-сучасному, на принципах людської гідності, науки та правових засад життя людей, яке на сьогодні є, як ніколи раніше, складним та обтяженим різними викликами: глобалізації, екології, кризовим станом суспільно- політичного розвитку [цит. за 4, с. 83-84].

На даному етапі розвитку світового суспільства особлива увага приділяється таким загальнолюдським цінностям як свобода та людська гідність [8, с. 153]. Вони же разом із цінностями рівності та солідарності $\epsilon$ найголовнішими цінностями для європейського суспільства. Окрім того, як можна побачити з попереднього аналізу, обидві ці цінності походять з християнства й не чужі для української національної традиції, хоча їх сприйняття певною мірою відрізняється від загальноєвропейського.

Цінність людської гідності безпосередньо походить від християнської моралі, у межах якої ставлення до людини ґрунтується на вихідній тезі про те, що людина - абсолютна цінність, найвища субстанція, «міра всіх речей». Адже вона розглядається як образ Божий, як творіння Боже. Підставою гідності людини, що носить незатертий образ Божий, $є$ відкритість до спілкування 3 Богом і ближніми та відкритість до трансцендентності. Гідність людини, згідно з етимологією «носити в собі Бога», висуває перед іншими людьми вимогу ії визнання і поваги. Гідність людини полягає в тому, що вона, як Боже творіння, є здатна пізнавати, любити свого Творця. Вона 
поставлена Богом бутиволодарем над усіма земними творіннями, ними керувати й користуватися благами, прославляти Творця [9].

Людську гідність протягом століть возвеличують поети, письменники та соціальні мислителі. Це поняття здобуло осмислення у фрілософії, етиці та психології, де воно постає як особлива властивість особистості, що виявляється передусім в усвідомленні та переживанні людиною своєї соціально-психологічної цінності та індивідуально-психологічної самоцінності як об'єкта і суб'єкта культури [10, с. 71].

Варто відзначити, що не дивлячись на цінування людської гідності з давніх часів, протягом XX ст. гідність людини відчула неабиякі випробування. Дві жахливі світові війни, фашизм та тоталітаризм катастрофічно знецінили людину та особистість. Усвідомлюючи жахливі помилки минулого, європейське суспільство з другої половини минулого століття (після Другої світової війни та падіння фашистських режимів) не лише возвеличує людську гідність, але й розробляє правові гарантії ії̈ захисту, що знайшло втілення у національному законодавстві європейських країн та міжнародних правових актах.

Нині людська гідність у європейському суспільстві безперечна цінність. Стійкі тенденції цінування людської гідності та наслідування зразків відповідної поведінки політиками, економістами, широким загалом населення вже призвело до розквіту демократії й економіки в європейських країнах. Більш того, саме повага до людської гідності, стала основою європейської ідентичності. Ї̈̈ основою є мир, неприйняття будь-якої форми самоізоляції і надмірностей у захисті партійних, місцевих чи національних інтересів. Європейська ідентичність після падіння комунізму і відкриття шляху на Схід дозволила об'єднати під спільним прапором народи, які ще десятиліття тому не могли й уявити собі можливості разом брати участь у будівництві спільної Європи [11, с. 184]

У згадувані вище Хартії фундаментальних прав Європейського Союзу цінність людської гідності конкретизується правовими настановами. Зокрема, перший розділ Хартії «Гідність», окрім права на людську гідність, закріплює права тагарантії, які забезпечують гідне існування людської особистості в суспільстві: право на життя, право на особисту недоторканність, заборону катувань та інших жорстоких, нелюдських або таких, що принижують гідність, поводжень та покарань, свободу від рабства й підневільного стану [3].

Україна повертається до людини та цінування людської гідності набагато пізніше. Більш того, кілька поколінь українців протягом життя не знали що таке людська гідність. Хоча сьогодні в Україні людська гідність постає як етико-правова категорія й цілих п'ять статей Основного Закону - Конституції України містять посилання на цей феномен як на засадниче положення, людська гідність поки не стала справжньою цінністю для більшості українців.

У сучасній вітчизняній філософській та психолого-педагогічній літературі чимало уваги приділяється проблематиці людини та гуманізації людських відносин. Захист, цінування та піднесення людської гідності розглядається як особливий аспект гуманізації відносин, оскільки людина, яка є їх суб'єктом, сама стає основною цінністю та безпосереднім об'єктом їх взаємодії. Ціннісне ставлення до людини містить у собі почуття ії цінності, ії моральної самобутності (І. Бех, М. Боришевський). Розвинене ставлення до іншої людини як цінності, зазначає Ю. А. Карпюк, означає: по-перше, прагнення та здатність індивіда співпереживати ії радості і горю; по-друге, бажання ії зрозуміти; по-третє, всіляке сприяння досягненню нею морально значущих цілей у повсякденній діяльності [12].

Зрозуміло, що одних тільки психологічних та педагогічних зусиль недостатньо для утвердження конституційних етико-правових норм українського громадянина щодо людської гідності та честі (у Конституції України категорію «гідність» незмінно супроводжує інша моральна категорія «честь»). Потрібна докорінна зміна суспільної свідомості на користь розуміння усіма громадянами переваг честі та гідності перед безчестю та негідністю у повсякденному суспільному житті, в політиці, економіці, трудовій і професійній діяльності [10, с. 82].

Цінність свободи лише опосередковано пов'язана з християнською мораллю. В результаті діяльності просвітителів у XVIII ст. Європа майже повсюдно стала сприйматися як континент свободи, вільнодумства і прогресу, що протистоїть «азійській» відсталості і деспотизму. Окрім того, вже в Новий час зусиллями європейських мислителів Т. Гоббса, Дж. Локка, Ж.-Ж. Руссо, І. Канта були сформульовані фундаментальні права і свободи людини, що залишаються й сьогодні наріжними каменями європейської політики. Це, насамперед, «природні, невідчу- 
жувані» права і свободи людини: право на життя, тобто свобода розпоряджатися своїм життям, право на власність, або свобода розпоряджатися своєю законно здобутою власністю, та право на свої переконання, тобто свобода совісті. «Природність» цих прав мовою того часу означала їх універсальність (притаманність всім людям) та те, що людина їх має від природи, вони не даровані їй ніким як привілеї - ані державою, ані іншими людьми, а «невідчужуваність» розуміли таким чином, що ніхто, особливо держава, не може їх порушувати, відбирати (відчужувати). Навпаки, саме держава повинна захищати ці права [3, с. 11].

3 часом утверджувались інші права і свободи (політичні, соціальні, культурні) й держава ставала на їх захист. Отже, свобода в усіх її проявах - особиста, соціально-економічна, правова, політична, мовна, культурна, свобода пересування тощо ставала найважливішою цінністю та ідеалом європейського суспільства. Класичне визначення свободи дав К. Маркс. Він писав: «Свобода - є право робити все те і займатися всім тим, що не шкодить іншому. Межі, в яких кожен може рухатися без шкоди для інших, визначаються законом подібно до того, як кордон двох ланів визначається межовим стовпом» [13, с. 372].

В ліберальній думці і політичній практиці виокремлюються поняття «свобода» («freedom») та «свободи» («liberties»). Перше означає невтручання держави або інших людей у сферу самовизначення людини. Ця сфера окреслюється згадуваними вище фундаментальними правами і свободами. Тобто індивід сам вільний розпоряджатися своїм життям, своєю законною власністю та визначати цінності, сенси свого життя. Ані держава, ані інші люди не можуть позбавити (відчужити) ці права і свободи людини. Це означає, що ліберально-демократична держава і суспільство не можуть експропріювати власність індивіда, позбавити або обмежити його життя через незаконне катування і страту, або засудити його за релігійні і політичні переконання. Держава не може втручатися у приватне життя людини, визначати, з ким їй укладати шлюб, дружити або як виховувати дітей та яким цілям присвятити своє життя. Свободи («liberties») ж в ліберальнодемократичному суспільстві розуміються як всі ті політичні, соціальні і культурні права й свободи, що слугують реалізації вищевказаної фундаментальної свободи («freedom») [14, с. 20-21]

У розділі II «Свободи» Хартії фрундаментальних прав Європейського Союзу (статті 6-19) 3осереджено увагу на фундаментальних громадянських та політичних свободах, закріплених в європейській конвенції з прав людини - Конвенції про захист прав людини і основоположних свобод, що прийнята Радою Європи 4 листопада 1950 року (зі змінами та доповненнями, внесеними Протоколом № 11 від 11 травня 1994 року та Протоколом № 14 від 13 травня 2004 року) $[15$, с. 628].

Окрім того, існують певні розбіжності між західним та східним вектором реалізації свободи. У традиційному східному соціумі свобода розглядається як цінність індивідуального буття, що відкриває можливість перемоги над внутрішньою природою, навіть відмови від власного «Я». Досягнення свободи тут можливо через усвідомлення себе як органічної складової оточуючого світу, своєї єдності з ним, що обумовлює сприйняття зовнішньої необхідності як своєї власної. Найбільш істотним $€$ те, що особистісна активність звернена тут не назовні, а всередину себе на власне вдосконалення.

Такий східний вектор реалізації свободи певною мірою властивий Україні, що знаходиться на межі цивілізаційних кордонів. Окрім того, українство, зазначає В. Г. Табачковський, позбавлене упродовж століть можливості справжнього духовного самовизначення, відчуваючи на протязі тривалого часу свого історичного існування тягар пригнічення, перебуваючи у межах «лабіринту несвободи», сформувало занадто романтичне уявлення про свободу, що на практиці здатне трансформуватися у «безмежність» і, в кінцевому підсумку, привести до сваволі [16, с. 40].

Натомість у сучасній інноваційній (західній) цивілізації свобода, в першу чергу, розглядається в діяльнісному аспекті, в плані креативного ставлення до світу як цінність суспільного буття. Таким чином, свобода як головна морально-аксіологічна домінанта західного світу виступає засобом вирішення проблеми взаємодії людини і світу; особистісне «Я» при цьому набуває пріоритетного значення по відношенню до зовнішньої реальності і спрямовує власну активність на ії перетворення [17, с. 161-162].

У зв'язку з цим для західної цивілізації набуває особливої актуальності проблема подолання такого «егоїстичного» ставлення до природного та соціального світів, що є наслідком поширення індивідуалізму. Ця проблема традиційно вирішується шляхом усвідомлення того, що людина як суб'єкт вільного самоствердження має розглядати не лише себе, а й інших особистостей таки- 
ми, які теж володіють свободою. Відповідно найвищим проявом людської свободи у зв'язку з цим виступає саме здатність до самообмеження, завдяки чому виявляється можливим здійснення свободи всіх [18, с. 153].

Саме у контексті реалізації свободи набуває вирішального значення цінність відповідальності, яка визначає межі свободи кожного окремого індивіду. Відповідальність також не є чужою для українського суспільства цінністю. Проте, як виявляється, відповідальність, як й свобода, також має різні прояви. Зокрема, зазначає А. Єрмоленко, варто розрізняти монологічну та дискурс-етичну відповідальності, що розвивались у різних суспільних системах. Монологічна відповідальність передбачає відповідальність особистості «за» свої вчинки. Вона здобула прояв у патерналізмі тоталітарних режимів, розділивши людей на так би мовити відповідальних та таких, що позбавлені цієї якості. Цей тип, основу якого складають традиційне гіпертрофоване піклування про оточуючих та відповідні доброчинності, базується на конвенційному етосі. Діалогічна відповідальність, що реалізується через відповідальність «перед» іншими людьми, групами та всім соціумом у цілому забезпечується демократичним механізмом дискурсивної етики. Це колективна відповідальність зрілих особистостей, які, спираючись на принцип справедливості, прагнуть узгодити інтереси та досягти консенсусу на основі діалогу [19, с. 21-24].

Висновки. Очевидно, українському суспільству добре знайома перша форма відповідальності. Діалогічній же відповідальності, що виявляється у вмінні узгоджувати різнопланові інтереси, шукати компроміс та приймати демократичні рішення у контексті європейських традицій українці ще мають навчитися.

\section{Література}

1. Кудряченко, А.І. Європейські цінності та їх вплив на розбудову країн молодої демократії / А. І. Кудряченко // Науковий вісник Дипломатичної академії України. - 2012. - Вип. 19. - С. 62-68.

2. Амельченко, Н. А. Цінності об'єднаної Європи [Електронний ресурс] / Н. А. Амельченко. - К.: ГО «Лабораторіязаконодавчих ініціатив», 2013. - 42 с. - Режим доступу: http://parlament.org.ua/upload/docs/European_Values.pdf.

3. Хартия основных прав Европейского Союза Торжественная прокламация (Ницца, $\overline{7}$ декабря 2000 года) [Електронний ресурс]. - Режим доступу: http://zakon0.rada.gov.ua/laws/show/994_524.

4. Пірен, М. І. Європейські цінності та їх реалізація у сфері державної служби та кадрової політики України / М.І. Пірен //Збірник наукових праць Національної академії державного управління при Президентові України. - 2015. - № 1. - С. 78-90.

5. Колесніченко, В. В. Принципи права Європейського Союзу: загальнотеоретичне дослідження : автореф. дис. канд. юрид. наук : спец. 12.00.01 «Теорія та історіядержави і права; історія політичних і правових учень» / В. В. Колесніченко. - Одеса, 2010.

6. Treaty establishing a Constitution for Europe. - Luxembourg: Office for Official Publications of the European Communities, $2005-482 \mathrm{p}$.

7. Русенко, І. Філософсько -правове розуміння принципів права у правовій системі Європейського Союзу/ Ірина Русенко // Публічне право. - 2014. - № 1 (13). - С. 231-238.

8. Борінштейн, Є. Р. Трансформація аксіосфери сучасного українського суспільства / Є. Р. Борінштейн, Ю. С. Юркевич // Наукове пізнання: методологія та технологія. - 2014. - № 1 (32). - С. 150-155.

9. Волкова, Н. М. Цінність людського життя в контексті християнської етики та біоетики [Електронний ресурс] / Н. М. Волкова, Г. Т. Терешкович, Т. І. Толокова. - Режим доступу: http://obljustif.gov.ua/wp-content/uploads /2013/06/Volkova.pdf.

10. Рибалка, В. Честь і гідність особистості як етико-правові і психолого-педагогічні категорії науки і життя людини / Валентина Рибалка // Естетика і етика педагогічної дії: зб. наук. праць. - 2011. - Вип. 1. - С. 68-84.

11. Кац, Е. Проблеми фрормування європейської ідентичності / Еліна Кац // Studia politologica Ucraino-Polona. - 2011. - Вип. 1. - С. 181-186.

12. Карпюк, Ю. А. Християнська мораль як засіб утвердження абсолютної цінності людини [Електронний ресурс] / Ю. А. Карпюк // Вісник Національної академії Державної прикордонної служби України. Серія: Психологічні науки : електрон. наук. фрах. вид. - 2012. - Вип. 3. -. Режим доступу : http://www.nbuv.gov.

13. Маркс К., Енгельс Ф. Вибрані твори, Т. 1. - К., 1958. - 670 с.

14. Чекаленко, Л. Європейські цінності - основні принципи європейської інтеграції / Людмила Чекаленко // Україна дипломатична. - 2013. - Вип. 14. - С. 628-640.

15. Табачковський, В. Г. «Лабіринти свободи» у вітчизняному марксистському та постмарксистському антропологізмі // Людина в цивілізації XXI століття: проблема свободи / М. О. Булатов, Т. В. Лютий, Г.І.Шалашенко, Є. І. Андрос, А. М. Дондюк, Г. П. Ковадло, Н. В. Хамітов, О. А. Ярош, В. П. Загороднюк. - К. : Наукова думка, 2005. - C. 34-48.

16. Баева, Л. В. Ценности изменяющегося мира: экзистенциальная аксиология истории: монография / Л. В. Баева. - Астрахань : Издательский дом «Астраханский университет», 2004. - 277 с.

17. Борінштейн, Є. Р. Трансформація аксіосфери сучасного українського суспільства / Є. Р. Борінштейн, Ю. С. Юркевич // Наукове пізнання: методологія та технологія. - 2014. - № 1 (32). - С. 150-155. 
18. Єрмоленко, А. Монологічна та дискурс-етична моделі відповідальності у суспільстві за добиреконструкції / А. Єрмоленко // Цінності громадянського суспільства і моральний вибір : український досвід. - К. : Етна-1. - 2006. - С. 13-31.

\section{References}

1. Kudriachenko, A. I. (2012). Yevropeiski tsinnosti ta yikh vplyv na rozbudovu krain molodoi demokratii [European values and their influence on the development of young democracies]. Naukovyi visnyk Dyplomatychnoi akademii Ukrainy - Scientific Bulletin of Diplomatic Academy of Ukraine, 19, $62-68$ [in Ukrainian].

2. Amelchenko, N. A. (2013). Tsinnosti obiednanoi Yevropy [Values of the united Europe]. parlament.org.ua. Retrieved from http://parlament.org.ua/upload/docs/European_Values.pdf [in Ukrainian].

3. Khartiya osnovnykh prav Evropeyskogo Soyuza Torzhestvennaya proklamatsiya (Nitstsa, 7 dekabrya 2000 goda)

[Charter of Fundamental Rights of the European Union Solemn Proclamation (Nice, December 7, 2000)]. (n.d.). zakon.rada.gov.ua. Retrieved from http://zakon0.rada.gov.ua/laws/show/994_524 [in Russian].

4. Piren, M. I. (2015). Yevropeiski tsinnosti ta yikh realizatsiia u sferi derzhavnoi sluzhby ta kadrovoi polityky Ukrainy [European Values and Their Implementation in the Field of Civil Service and Personnel Policy of Ukraine]. Zbirnyk naukovykh prats Natsionalnoi akademii derzhavnoho upravlinnia pry Prezydentovi Ukrainy - Collection of scientific works of the National Academy of Public Administration under the President of Ukraine, 1, 78-90 [in Ukrainian].

5. Kolesnichenko, V. V. (2010). Pryntsypy prava Yevropeiskoho Soiuzu: zahalno-teoretychne doslidzhennia [Principles of law of the European Union: general theoretical research]. Extended abstract of candidate's thesis. Odesa [in Ukrainian].

6. Treaty establishing a Constitution for Europe. (2005). Luxembourg: Office for Official Publications of the European Communities [in Ukrainian].

7.Rusenko, I. (2014). Filosofsko-pravove rozuminnia pryntsypiv prava u pravovii systemi Yevropeiskoho Soiuzu [Philosophical and legal understanding of the principles of law in the legal system of the European Union]. Publichne pravo - Public law, 1(13), 231-238 [in Ukrainian].

8. Borinshtein, Ye. R., Yurkevych, Yu. S. (2014). Transformatsiia aksiosfery suchasnoho ukrainskoho suspilstva [The Transformation of the Axisosphere of Modern Ukrainian Society]. Naukove piznannia: metodolohiia ta tekhnolohiia - Scientific knowledge: methodology and technology, 1(32), 150-155 [in Ukrainian].

9. Volkova, N. M., Tereshkovych, H. T., Tolokova, T. I. (2014). Tsinnist liudskoho zhyttia v konteksti khrystyianskoi etyky ta bioetyky [The value of human life in the context of Christian ethics and bioethics]. Visnyk Prykarpatskoho universytetu. Politolohiia - Journal of Precarpathian University. Political Science, 8, 79-84. Retrieved from http://obljustif.gov.ua/wpcontent/uploads/2013/06/Volkova.pdf [in Ukrainian].

10. Rybalka, V. (2011). Chest i hidnist osobystosti yak etyko-pravovi i psykholoho-pedahohichni katehorii nauky i zhyttia liudyny [Honor and dignity of the individual as ethical and legal and psychological and pedagogical categories of science and human life]. Estetyka i etyka pedahohichnoi dii - Aesthetics and ethics of pedagogical action, 1, 68-84 [in Ukrainian].

11. Kats, E. (2011). Problemy formuvannia yevropeiskoi identychnosti [Problems of forming a European identity]. Studia politologica Ucraino-Polona, 1, 181-186 [in Ukrainian].

12. Karpiuk, Yu. A. (2012). Khrystyianska moral yak zasib utverdzhennia absoliutnoi tsinnosti liudyny [Christian morality as a means of asserting the absolute value of man]. Visnyk Natsionalnoi akademii Derzhavnoi prykordonnoi sluzhby Ukrainy. Seriia: Psykholohichni nauky - Bulletin of the National Academy of the State Border Guard Service of Ukraine. Series: Psychological Sciences, 3. Retrieved from http://nbuv.gov.ua/UJRN/Vnadps 2012 3 30 [in Ukrainian].

13. Marks K., Enhels F. Vybrani tvory [Marks K., Engels F. Selected Works]. (1958). (Vols. 1). Kyiv [in Ukrainian].

14. Chekalenko, L. (2013). Yevropeiski tsinnosti - osnovni pryntsypy yevropeiskoi intehratsii [European values - the basic principles of European integration]. Ukraina dyplomatychna - Ukraine diplomatic, 14, 628-640 [in Ukrainian].

15. Tabachkovskyi, V. H., et al. (2005). "Labirynty svobody» u vitchyznianomu marksystskomu ta postmarksystskomu antropolohizmi ["Labyrinths of freedom" in domestic Marxist and post-Marxist anthropologism]. Liudyna v tsyvilizatsii XXI stolittia: problema svobody - Man in the civilization of the XXI century: the problem of freedom. (pp. 34-48). Kyiv: Naukova dumka [in Ukrainian].

16. Baeva, L. V. (2004). Tsennosti izmenyayushchegosya mira: ekzistentsialnaya aksiologiya istorii [Values of the changing world: existential axiology of history]. Astrakhan: Izdatelskiy dom «Astrakhanskiy universitet» [in Russian].

17. Borinshtein, Ye. R., Yurkevych, Yu. S. (2014). Transformatsiia aksiosfery suchasnoho ukrainskoho suspilstva [The Transformation of the Axisosphere of Modern Ukrainian Society]. Naukove piznannia: metodolohiia ta tekhnolohiia - Scientific knowledge: methodology and technology, 1(32), 150-155 [in Ukrainian].

18. Yermolenko, A. (2006). Monolohichna ta dyskurs-etychna modeli vidpovidalnosti u suspilstvi za dobyrekonstruktsii [Monological and Discourse-Ethical Models of Responsibility in Society for Pre-Constructions]. Tsinnosti hromadianskoho suspilstva i moralnyi vybir:ukrainskyi dosvid - Values of Civil Society and Moral Choice: Ukrainian Experience. (pp. 13-31). Kyiv: Etna-1 [in Ukrainian].

Бібліографічний опис для цитування :

Надійшла 16.10.2018

Ігнатко, В. С. Духовне оновлення українського суспільства в контексті європейських традицій / В. С. Ігнатко // Проблеми соціальної роботи: філософія, психологія, соціологія. - 2018. - № 2 (12). - С. 44-50. 